\title{
EVALUATION OF PHOSPHORUS IN FOREST SOILS: COMPARISON OF PHOSPHORUS UPTAKE, EXTRACTION METHOD AND SOIL PROPERTIES*
}

\author{
by O. KADEBA and J. R. BOYLE** \\ Savanna Forestry Research Station, P.M.B. 1039, \\ Samaru, Zaria, Nigeria
}

\section{SUMMARY}

Phosphorus in soils from plantation of red pine (Pinus resinosa Ait.) was determined using six extractants: $0.002 \mathrm{~N} \mathrm{H}_{2} \mathrm{SO}_{4}(\mathrm{pH} 3.0) ; 0.025 \mathrm{~N} \mathrm{HCl}+$ $+0.03 \mathrm{~N} \mathrm{NH}_{4} \mathrm{~F} ; 0.5 N \mathrm{NaHCO}_{3}(\mathrm{pH} 8.5) ; \mathrm{N} \mathrm{NH}_{4} \mathrm{OAc}(\mathrm{pH} 4.8)$; anion exchange resin (Dower $-2, \mathrm{Cl}-$ form) $; \mathrm{H}_{2} \mathrm{O}$. Correlations of extractable $\mathrm{P}$ with $\mathrm{Al}-$ and $\mathrm{Al}-\mathrm{Fe}-\mathrm{P}$ indicated that these fractions are the dominant forms of inorganic $\mathrm{P}$ in most of the soils.

Uptake of $\mathrm{P}$ by corn and Monterey pine seedlings grown in greenhouse culture was correlated with soil $\mathrm{P}$ extracted by the different methods. The most successful of the extractants for predicting $\mathrm{P}$ uptake was resin extractable $\mathrm{P}$; the simple correlation coefficients were 0.811 and 0.609 for pine and corn respectively. $\mathrm{P}$ uptake by pine correlated significantly with $0.002 \mathrm{~N} \mathrm{H}_{2} \mathrm{SO}_{4} \mathrm{P}$ $(\mathrm{r}=0.679), N \mathrm{NH}_{4} \mathrm{OAc} \mathrm{P}(\mathrm{r}=0.443), \mathrm{H}_{2} \mathrm{O} \mathrm{P}(\mathrm{r}=0.549)$ and Al- $+\mathrm{Fe}-\mathrm{P}$ (r $=0.532$ ) while $\mathrm{P}$ uptake by corn correlated with $0.002 \mathrm{~N}_{2} \mathrm{H}_{2} \mathrm{SO}_{4} \mathrm{P}$ $(\mathrm{r}=0.579), \mathrm{H}_{2} \mathrm{O} \mathrm{P}(\mathrm{r}=0.477)$ and organic $\mathrm{P}(\mathrm{r}=0.460)$. Per cent $\mathrm{P}$ in pine seedling tops correlated significantly with $0.002 \mathrm{~N} \mathrm{H}_{2} \mathrm{SO}_{4}$, resin and $\mathrm{N} \mathrm{\textrm {NH } _ { 4 }}$ OAc extractable P. Multiple regressions which included silt + clay and organic $\mathbf{P}$ improved correlations of some soil tests with $\mathbf{P}$ uptake in corn and pine seedlings respectively.

\section{INTRODUCTION}

The different procedures for estimating available phosphorus have often been compared and their relative efficiency judged by the degree of correlation obtained with $\mathrm{P}$ uptake by plants in either green-

* Research supported by the School of Natural Resources, College of Agricultural and Life Sciences, Univ. of Wisconsin, Madison, the Wisconsin Department of Natural Resources and FAO Fellowship to the senior author.

** School of Natural Resources, University of Michigan, Ann. Arbor, U.S.A. 
house or fields trials 1726 . The popularity of this approach is due to the fact that comparison of soil test values with analyses of plant grown on the soil offers a simple and rapid method of evaluating the soil tests under a wide variety of conditions, especially where data on response to fertilizer is limiting or lacking 20 .

Chemical analyses for assessing potential productivity of forest soils have included determinations of 'available' or 'extractable' phosphorus ${ }^{24}$. Extractable soil $\mathrm{P}$ has been correlated with the growth of red pine (Pinus resinosa Ait.) in Wisconsin ${ }^{31}$, New York ${ }^{8}$, and Minnesota $^{1}$, with the uptake of $\mathrm{P}$ by pitch pine (Pinus rigida Mill.) in New Jersey ${ }^{29}$, and with growth of Ocala sand pine (Pinus clausa (Chapm.) Vasey) seedlings in greenhouse cultures ${ }^{4}$. Limited consideration has been given to determination of the forms or fractions of soil $\mathrm{P}$ which are utilized by trees ${ }^{1}{ }^{29}$.

The objectives of this study were to further evaluate methods of estimating soil $\mathrm{P}$ available to forest trees under greenhouse conditions by (i) Comparison of amounts of $\mathrm{P}$ extractants; (ii) correlation of extractable $\mathrm{P}$ with forms of $\mathrm{P}$ in soils; (iii) correlation of extractable soil $P$ with plant uptake of $P$.

\section{MATERIALS AND METHODS}

Soils

Soil samples for this study were collected in June 1972 from 30 red pine plantations in Wisconsin. The soils were selected to represent a range of levels of analytically determined available phosphorus. The plantations which varied in age were confined mostly to acid sandy soils except for a few which were on fine-textured soils. In a state-wide survey, Wilde et al. ${ }^{31}$ have documented in detail the chemical and physical characteristics of these soils and included data on plantation growth measurements. Larsen* in a similar state-wide soil-site study of red pine has updated information on these soils and plantations. In each plantation about $10 \mathrm{~kg}$ of composite sample were collected from the top $15 \mathrm{~cm}$ of soil after scraping off surface litter ( 0 horizons). Samples were air-dried, thoroughly mixed and passed through a $2 \mathrm{~mm}$ sieve. Given in Table 1 are selected characteristics of the soils used in this study.

\section{Chemical analyses}

All laboratory analyses were performed in duplicate on soils that had been screened through a 60 mesh sieve. Extractable phosphorus was determined by

* Larse n, R. L., Soil-site relationships of red pine in Wisconsin. M. S. Thesis, University of Wisconsin-Madison (1972). 
using six procedures. In all cases phosphorus in the filtered soil extract was measured colorimetrically by the method of Murphy and Riley ${ }^{17}$ as modified by John ${ }^{14}$ using ascorbic acid as reductant.

The procedures were: (1) $0.002 \mathrm{~N} \mathrm{H}_{2} \mathrm{SO}_{4}$ buffered to $\mathrm{pH} 3.0$ with $\left(\mathrm{NH}_{4}\right)_{2}$ $\mathrm{SO}_{4}$ (Truog ${ }^{28}$ ). (2) $0.0025 \mathrm{~N} \mathrm{HCl}$ and $0.03 \mathrm{~N} \mathrm{NH}_{4} \mathrm{~F}$ (Bray and Kurtz${ }^{5}$ ). (3) $0.5 \mathrm{~N} \mathrm{NaHCO}_{3}$ adjusted to $\mathrm{pH} 8.5$ with $\mathrm{NaOH}$ (Olsen et al. 18). (4) $1 \mathrm{~N}$ $\mathrm{NH}_{4} \mathrm{OAc}$ adjusted to $\mathrm{pH} 4.8$ with acetic acid (Pritchett and Llewelly ${ }^{23}$ ). (5) Anion-exchange resin (Amer et al. ${ }^{2}$ ). (6) $\mathrm{H}_{2} \mathrm{O}$ (Van der $\mathrm{Pa}$ a uw ${ }^{19}$ ).

Analytical procedures for determination of total, inorganic and organic $\mathrm{P}$ were based on the method of Saunders and Williams ${ }^{25}$ as modified by Walker and Adams ${ }^{30}$. Al- and Fe- bound $\mathrm{P}$ were determined by the fractionation procedure of $\mathrm{Chang}$ and $\mathrm{Jackson}^{6}$ as modified by Petersen and Corey ${ }^{21}$.

\section{Greenhouse}

Phosphorus uptake from soils by two test crops, corn (Zea mays L.) and Monterey pine (Pinus radiata D. Don.) was used to evaluate the phosphorus soil tests.

For growth of tree seedlings, soils were placed in glazed pots previously washed with acid solution and rinsed with distilled water. Equal volumes of soil were measured into each pot. The weights of soil used varied between 1.5 and $2.2 \mathrm{~kg}$ depending on the volume weight of each soil. The preference for this approach was based on the concept that plants generally explore soil for nutrients on volume rather than on weight basis. Corn seedlings were grown in smaller plastic containers which were filled with equal volumes of soils; the weights of soil varied between 860 and $1200 \mathrm{~g}$. Each plant-soil combination was replicated twice.

Soils were wetted to field capacity with small portions of water at a time to obtain a uniform moisture distribution. Seeds of test plants were sown directly in the pots. After a period of growth, the corn seedlings were thinned to 4 uniform seedlings per pot and pine initially to 10 and later to 6 seedlings per pot owing to loss of some seedlings due to damping-off disease*. To reduce the severity of damping-off and prevent further loss of seedlings, the pine cultures were twice treated according to manufacturer's prescription with Captan 50WP.

To ensure adequacy of nutrients other than $P$ each pot received a total of $100 \mathrm{ml}$ of phosphorus-free nutrient solution during the growth period (I y er*). Pots were arranged on greenhouse benches in a completely randomized design, watered to field capacity daily and periodically rotated as to position to reduce variability in light intensity. Day lengths were increased to 16 hours by artificial lighting. In summer, temperature in the greenhouse ranged between 17 and $37^{\circ} \mathrm{C}$; in the winter months the temperature varied between 16 and $27^{\circ} \mathrm{C}$.

* I yer, J. G., Trace elements (Mn, B, Cu and Mo); their effect on the growth of trees, particularly Pinus resinosa, Robinia pseudoacacia, and Alnus glutinosa. M. S. Thesis, University of Wisconsin-Madison (1963). 
The above-ground parts of the corn and pine seedlings were har vested after 6 and 23 weeks of growth respectively. Tissues were oven-dried at $50-60^{\circ} \mathrm{C}$, weighed and ground in preparation for chemical analyses. Tissue samples were analysed for total $\mathrm{P}$ by the Wisconsin State Soil Testing Laboratory. The procedure involved ashing $\frac{1}{2} \mathrm{~g}$ of tissue at $500^{\circ} \mathrm{C}$ for 2 hours. Phosphorus content of ash was colorimetrically determined by the vanado-molybdophosphoric yellow colour method ${ }^{13}$.

TABLE 1

Selected soil characteristics

\begin{tabular}{|c|c|c|c|c|c|c|}
\hline \multirow{2}{*}{$\begin{array}{c}\text { Soil } \\
\text { number }\end{array}$} & \multirow{2}{*}{$\underset{\left(\mathbf{H}_{2} \mathrm{O}\right)}{\mathrm{pH}}$} & \multirow{2}{*}{$\begin{array}{c}\text { Org. } \\
\text { matter } \\
\%\end{array}$} & \multirow{2}{*}{$\begin{array}{c}\text { Silt }+ \\
\text { clay } \\
\%\end{array}$} & \multicolumn{3}{|c|}{ Exch. cations meq/100 g soil } \\
\hline & & & & $\overline{\mathrm{Ca}}$ & $\mathrm{Mg}$ & $\bar{K}$ \\
\hline 1 & 4.8 & 1.6 & 8 & 0.36 & 0.27 & 0.04 \\
\hline 2 & 4.9 & 2.4 & 53 & 5.63 & 2.50 & 0.25 \\
\hline 3 & 4.8 & 2.1 & 6 & 0.73 & 0.37 & 0.05 \\
\hline 4 & 6.6 & 3.4 & 70 & 8.93 & 3.33 & 0.25 \\
\hline 5 & 6.3 & 2.5 & 48 & 4.86 & 2.83 & 0.13 \\
\hline 6 & 6.1 & 3.3 & 44 & 6.36 & 4.12 & 0.23 \\
\hline 7 & 6.3 & 4.5 & 52 & 7.95 & 3.37 & 0.28 \\
\hline 8 & 7.0 & 3.1 & 72 & 8.84 & 5.40 & 0.25 \\
\hline 9 & 6.4 & 3.2 & 11 & 2.34 & 2.54 & 0.07 \\
\hline 10 & 5.2 & 2.8 & 10 & 1.10 & 0.62 & 0.06 \\
\hline 11 & 5.2 & 1.7 & 9 & 0.50 & 0.29 & 0.08 \\
\hline 12 & 5.5 & 1.8 & 6 & 0.63 & 0.25 & 0.06 \\
\hline 13 & 5.3 & 1.9 & 7 & 0.25 & 0.10 & 0.04 \\
\hline 14 & 5.3 & 4.0 & 10 & 1.38 & 0.48 & 0.07 \\
\hline 15 & 5.2 & 3.1 & 11 & 1.00 & 0.21 & 0.05 \\
\hline 16 & 5.4 & 1.4 & 28 & 1.00 & 0.40 & 0.09 \\
\hline 17 & 5.4 & 2.5 & 35 & 1.00 & 0.27 & 0.10 \\
\hline 18 & 5.6 & 1.7 & 17 & 1.50 & 0.19 & 0.06 \\
\hline 19 & 5.1 & 2.1 & 13 & 0.75 & 0.17 & 0.08 \\
\hline 20 & 5.4 & 1.9 & 24 & 0.75 & 0.27 & 0.09 \\
\hline 21 & 5.4 & 1.8 & 16 & 0.28 & 0.15 & 0.08 \\
\hline 22 & 5.4 & 2.7 & 38 & 3.25 & 0.27 & 0.13 \\
\hline 23 & 5.1 & 1.9 & 25 & 1.25 & 0.33 & 0.13 \\
\hline 24 & 5.3 & 1.2 & 40 & 2.13 & 0.46 & 0.15 \\
\hline 25 & 5.4 & 2.5 & 39 & 2.00 & 0.48 & 0.15 \\
\hline 26 & 5.4 & 2.2 & 25 & 2.13 & 0.33 & 0.13 \\
\hline 27 & 5.3 & 1.8 & 8 & 0.13 & 0.04 & 0.06 \\
\hline 28 & 5.0 & 1.2 & 10 & 0.25 & 0.31 & 0.10 \\
\hline 29 & 4.8 & 1.4 & 13 & 1.25 & 0.31 & 0.10 \\
\hline 30 & 4.8 & 1.3 & 13 & 1.13 & 0.37 & 0.23 \\
\hline
\end{tabular}




\section{RESULTS AND DISCUSSION}

\section{Soil analyses}

The mean and range of $\mathrm{P}$ extracted by different soil test methods, organic $\mathrm{P}, \mathrm{Al}$ - and Fe-bound $\mathrm{P}$ content of the soils are given in Table 2. Among the soil test methods for readily extractable $P$, Bray extracted the highest amount of $P$, except in some of the finetextured soils having a pH above 6 . The Olsen method, too, extracted relatively less $P$ from these soils. These results agree with investigations of soil inorganic $P$ by Pratt and Garber ${ }^{22}$. They found that heavy-textured soils are apt to decrease the efficiency of these reagents as $\mathbf{P}$ extractants because the reagents tend to react with clay minerals as well as with phosphate. Since hydrochloric acid can dissolve $\mathrm{Ca}-\mathrm{P}$, and fluoride in acid can complex $\mathrm{Al}-$ and $\mathrm{Fe}-$ $P$ efficiently, Bray's method tends to extract high amounts of $P$.

The Truog extractant removed generally less $\mathrm{P}$ than Bray's and extracted more $\mathrm{P}$ from the soils with high exchangeable Ca. Susuki et al. ${ }^{27}$ reported that Truog's method removed portions of $\mathrm{Ca}-\mathrm{P}$ and Al-P. Other extractants removed comparatively smaller amounts of $\mathrm{P}$ which would be mainly saloid bound and water soluble $\mathrm{P} 10$.

TABLE 2

Amount of $\mathbf{P}$ forms extracted and coefficients of determination of $\mathbf{P}$ uptake (mg/pot) and $P$ extracted

\begin{tabular}{|c|c|c|c|c|}
\hline \multirow[t]{2}{*}{ Form of $\mathrm{P}$} & \multicolumn{2}{|c|}{ Amount of $\mathrm{P}$ extracted, ppm } & \multicolumn{2}{|c|}{$\begin{array}{l}\text { Coefficient of } \\
\text { determination, } \mathrm{r}^{2}\end{array}$} \\
\hline & Range & $\begin{array}{c}\text { Mean } \\
-\end{array}$ & $\begin{array}{c}\text { Corn } \\
(n=29)\end{array}$ & $\begin{array}{c}\text { Pine } \\
(\mathrm{n}=25)\end{array}$ \\
\hline $0.002 \mathrm{~N} \mathrm{H}_{2} \mathrm{SO}_{4}$ & $5.0-36.0$ & 19.7 & $0.366 * *$ & $0.461 * *$ \\
\hline $0.025 N \mathrm{HCl}+0.03 \mathrm{~N} \mathrm{NH}_{4} \mathrm{~F}$ & $6.0-120.0$ & 34.1 & -0.046 & 0.078 \\
\hline $1 \mathrm{~N} \mathrm{NH}_{4} \mathrm{OAc}$ & $1.3-9.7$ & 4.7 & 0.006 & $0.196 *$ \\
\hline $0.5 \mathrm{~N} \mathrm{NaHCO}_{3}$ & $2.0-37.0$ & 14.3 & 0.012 & 0.114 \\
\hline Resin & $1.0-11.4$ & 5.3 & $0.372 * *$ & $0.658 * *$ \\
\hline $\mathrm{H}_{2} \mathrm{O}$ & $0.3-5.6$ & 1.9 & $0.228 *$ & $0.298 * *$ \\
\hline Al-P & $16-194$ & 60 & 0.011 & $0.241 *$ \\
\hline $\mathrm{Al}-+\mathrm{Fe}-\mathrm{P}$ & $56-297$ & 135 & 0.022 & $0.283 * *$ \\
\hline Org. P & $40-420$ & 166 & $0.212^{*}$ & 0.037 \\
\hline
\end{tabular}

** Significant at $1 \%$ level

* Significant at 5\% level 
In $\mathrm{P}$ fractionation procedures, the soils were analysed only for $\mathrm{Al}$ - and $\mathrm{Fe}$-bound $\mathrm{P}$ as these were assumed to be the dominant forms of inorganic $P$, particularly in the acid sandy soils. In soils $2,4,5,6$, 7 and 8 which were all fine-textured and high in exchangeable $\mathrm{Ca}$ (Table 1), the levels of Al-P and Fe-P as well as their sum were relatively low and accounted for less than $50 \%$ of total inorganic $\mathrm{P}$. It is likely that Ca-P might predominate in these soils; this conclusion is supported by the observation that Truog values in these soils were higher than the corresponding Bray values. Among the individual forms of soil $\mathrm{P}$, organic $\mathrm{P}$ constituted the highest amount. Its level in these soil varied according to texture and organic matter content.

\section{Correlations between soil test data and P forms}

Comparisons were made between the soil test values and $\mathrm{P}$ forms by means of linear regression analysis. The simple linear correlations coefficients between soil $\mathrm{P}$ fractions and $\mathrm{P}$ extracted by soil test methods are shown in Table 3. Most of the extractants correlated highly with Al-P, except $\mathrm{H}_{2} \mathrm{O}-\mathrm{P}$ and resin-P. Similar correlations were made between the sum of $\mathrm{Al}-\mathrm{P}$ and $\mathrm{Fe}-\mathrm{P}$ and soil test values. It appears that most of the methods used extracted some proportions of Al-P and Fe-P and to some extent other forms of $\mathrm{P}$.

The correlation coefficients (Table 3) showed that, although the amount of $\mathrm{P}$ extracted by the different methods varied, many of the results were well correlated. It is probably that the same form or forms of $\mathrm{P}$ were being extracted by two tests which were closely

TABLE 3

Simple correlation coefficients relating $P$ extracted by soil test methods and $P$ fractions

\begin{tabular}{|c|c|c|c|c|c|c|c|}
\hline & Bray P & $\begin{array}{c}\mathrm{NH}_{4} \mathrm{OAC} \\
\mathrm{P}\end{array}$ & Olsen $P$ & Resin $\mathrm{P}$ & $\mathrm{H}_{2} \mathrm{O} \mathrm{P}$ & Al-P & $\begin{array}{c}\mathrm{Al}-+ \\
\mathrm{Fe}-\mathrm{P}\end{array}$ \\
\hline Truog & $0.462^{*}$ & $0.806 * *$ & $0.652 * *$ & $0.637 * *$ & $0.506 * *$ & $0.781 * *$ & $0.763^{* *}$ \\
\hline Bray $P$ & & $0.627 * *$ & $0.792 * *$ & $0.331 \mathrm{~ns}$ & $0.030 \mathrm{~ns}$ & $0.777 * *$ & $0.704^{* *}$ \\
\hline $\mathrm{NH}_{4} \mathrm{OAc} \mathrm{P}$ & & & $0.722 * *$ & $0.433 * *$ & $0.375 * *$ & $0.680 * *$ & $0.587 * *$ \\
\hline Olsen P & & & & $0.402^{*}$ & $0.297 \mathrm{~ns}$ & $0.646 * *$ & $0.578 * *$ \\
\hline Resin $\mathbf{P}$ & & & & & $0.493 * *$ & $0.340 \mathrm{~ns}$ & $0.416^{*}$ \\
\hline $\mathrm{H}_{2} \mathrm{OP}$ & & & & & & $0.339 \mathrm{~ns}$ & $0.273 \mathrm{~ns}$ \\
\hline Al-P & & & & & & & $0.935 * *$ \\
\hline
\end{tabular}

** Significant at $1 \%$ level

* Significant at $5 \%$ level

ns not significant at $5 \%$ level 
correlated. However, this does not imply in all cases that the same or a proportional amount of $\mathrm{P}$ was being removed from each inorganic source by any two methods.

It has been reported ${ }^{7}$ that correlations between soil tests and $\mathrm{P}$ forms depend on which form of $\mathrm{P}$ is dominant in a soil. The highly significant and positive correlation between $\mathrm{P}$ extracted by four of the soil test methods and Al-P and sum of Al-P and Fe-P may well provide evidence in support of the assumption that these were perhaps the dominant forms of inorganic $\mathrm{P}$ in most of the soils.

\section{Correlations of $P$ uptake with soil tests}

The purpose of the greenhouse trial was to measure seedling $P$ uptake and use these to evaluate the various soil tests. Dry-matter yields, per cent tissue $\mathbf{P}$ and $\mathbf{P}$ uptake were determined for the test plants but only values of $\mathbf{P}$ uptake were used in final correlation and regression analyses because of weak or insignificant correlation of other parameters with soil tests. It was not possible to obtain plant growth indexes for pine on soils 4, 5, 7, 8 and 29 because of seedling death caused by damping-off disease.

Phosphorus extracted by Truog, resin, $\mathrm{H}_{2} \mathrm{O}$ and $\mathrm{NH}_{4} \mathrm{OAc}$ tests and $\mathrm{Al}-\mathrm{P}$ and sum of Al-P and Fe-P correlated with $\mathrm{P}$ uptake in pine; only $\mathrm{P}$ extracted by $\mathrm{T} r u o g$, resin and $\mathrm{H}_{2} \mathrm{O}$ methods correlated with $P$ uptake in corn (Table 2).

Bray and Olsen $\mathrm{P}$ did not correlate significantly with $\mathrm{P}$ uptake by any of the 2 test plants. Some workers have reported poor correlation between $\mathrm{Bray} \mathrm{P}$ and $\mathrm{P}$ uptake in barley tops ${ }^{27}$. The poor correlation observed between $\mathrm{P}$ uptake and Bray and Olsen tests might be related partly to the effect of texture on the extractants. It is likely, too, that these methods extracted proportions of soil inorganic $P$ that might give a better evaluation of long-term availability of $\mathrm{P}$ rather than short-term availability that are more relevant in greenhouse studies.

The same explanation might suffice for the lack of correlation of $\mathrm{Al}-\mathrm{P}$ and $\mathrm{Fe}-\mathrm{P}$ with $\mathrm{P}$ uptake in corn. Where textural variability was limited, as in the soils in which pine seedlings survived and grew, there was significant correlation between these $\mathrm{P}$ fractions and $\mathrm{P}$ uptake. Mutual correlations might have concealed some other wise significant correlations. For example, silt + clay content was negatively correlated with Al-P $(\mathrm{r}=-0.467)$ but positively and signi- 
ficantly correlated with $\mathrm{P}$ uptake by corn. Truog $\mathrm{P}$ showed the best correlation with Al-P and sum of Al-P and Fe-P (Table 3) and it was also highly correlated with $\mathrm{P}$ uptake by the test plants (Table 2). It appears that the Truog method met the requirement of extracting proportions of Al-P and Fe-P that were related to $\mathrm{P}$ uptake by the plants.

Resin extractable $\mathrm{P}$ correlated highly with $\mathrm{P}$ uptake of the test plants and in all cases was superior to any other single measurement for predicting $\mathrm{P}$ uptake. Advantages of the resin method are that it is not significantly influenced by soil characteristics such as texture and it does simulate the mode of $\mathrm{P}$ uptake by plants ${ }^{2}$. Considering the shaking period of 2 hours adopted in this study for resin extraction, it is thought that kinetic exchange of $P$ by the resin would be from soil solution as well as from readily exchangeable $\mathrm{P}$ from mineral surfaces. This then implies that resin extractable $\mathrm{P}$ is a composite value that should reflect both quantity and intensity factors involved in $\mathrm{P}$ uptake by plants. This is supported by the fact that both water extractable $\mathrm{P}$ and the sum of Al-P and Fe-P were significantly correlated with resin extractable $\mathrm{P}$. The suggestion that resin extractable $\mathrm{P}$ was a composite parameter agrees with other findings ${ }^{3}{ }^{9}$.

\section{Phosphorus uptake in relation to other soil properties}

Soil properties other than the forms of $P$ influence the amount of $\mathrm{P}$ absorbed from soil by a plant. In order to examine some of these and determine the merit of their inclusion in soil tests for routine evaluation of $\mathrm{P}$ availability, $\mathrm{pH}$, organic matter, organic $\mathrm{P}$ and silt + clay content were tested as additional independent variables. Multiple linear correlations of $\mathrm{P}$ uptake on each of the soil tests plus additional variables were computed in the combinations shown in Tables 4 and 5.

Among soil properties considered, silt + clay content increased significantly the correlation of $\mathrm{P}$ uptake with some of the soil tests. In most cases, when taken in combination with other variables only the effect of texture was significant. For example, in the multiple regression of $\mathrm{P}$ uptake by corn on Truog $\mathrm{P}$, organic $\mathrm{P}, \mathrm{pH}$, and silt + clay content, only the effect of silt + clay was significant in addition to Truog $\mathrm{P}$ judging from the $\mathrm{F}$ value (not shown). Based on the $\mathrm{F}$ values of the soil parameters, the results of multiple regression analyses could be summarized as follows: 1 . Addition of organic mat- 
TABLE 4

$\mathrm{R}^{2}$ values for multiple linear correlations of $\mathrm{P}$ uptake (mg/pot) by corn on each of the soil tests and other soil properties

\begin{tabular}{|c|c|c|c|c|c|c|c|c|}
\hline \multirow{2}{*}{$\begin{array}{c}\text { Soil } \\
\text { properties }\end{array}$} & \multicolumn{8}{|c|}{ Soil tests } \\
\hline & Truog P & Bray $P$ & $\begin{array}{c}\mathrm{NH}_{4} \mathrm{OAC} \\
\mathrm{P}\end{array}$ & $\begin{array}{c}\text { Olsen } \\
\mathbf{P}\end{array}$ & Resin & $\mathrm{H}_{2} \mathrm{OP}$ & $\mathrm{Al}-\mathrm{P}$ & $\begin{array}{l}\mathrm{Al}-+ \\
\mathrm{Fe}-\mathrm{P}\end{array}$ \\
\hline OM & $0.401 *$ & 0.089 & 0.136 & - & $0.376 * *$ & $0.241^{*}$ & 0.116 & 0.118 \\
\hline Org. $P$ & $0.489 * *$ & $0.215^{*}$ & - & $0.257^{*}$ & $0.402 * *$ & $0.336 * *$ & $0.249^{*}$ & $0.237^{*}$ \\
\hline $\mathrm{pH}$ & $0.415^{* *}$ & $0.194^{*}$ & 0.243 & $0.267^{*}$ & $0.398 * *$ & $0.247^{*}$ & $0.247^{*}$ & $0.223^{*}$ \\
\hline $\mathrm{SC}$ & $0.548 * *$ & $0.244 * *$ & $0.334 * *$ & $0.285^{*}$ & $0.448 * *$ & $0.342 * *$ & $0.356^{*}$ & $0.335^{*}$ \\
\hline $\mathrm{OM}+\mathrm{pH}$ & $0.420 * *$ & -+ & 0.243 & $0.278^{*}$ & $0.399 * *$ & $0.275^{*}$ & 0.229 & 0.226 \\
\hline $\mathrm{OM}+\mathrm{pH}+\mathrm{SC}$ & $0.564^{* *}$ & - & 0.341 & $0.345^{*}$ & $0.449 * *$ & $0.342^{*}$ & $0.367^{*}$ & $0.342 *$ \\
\hline Org. $\mathrm{P}+\mathrm{pH}$ & $0.494 * *$ & - & $0.322^{*}$ & $0.358^{*}$ & $0.415^{* *}$ & $0.346^{*}$ & $0.320^{*}$ & $0.304 *$ \\
\hline Org. $\mathrm{P}+\mathrm{pH}+\mathrm{SC}$ & $0.584 * *$ & - & $0.373^{*}$ & $0.386 *$ & $0.415^{* *}$ & $0.377^{*}$ & $0.402^{*}$ & $0.368^{*}$ \\
\hline
\end{tabular}

ter to correlations including soil tests did not significantly improve $\mathrm{R}^{2}$ values of $\mathrm{P}$ uptake with any soil test. 2 . Inclusion of organic $\mathrm{P}$ with the soil test values significantly improved the prediction of $\mathrm{P}$ uptake by pine from only Truog P, but improved predictions from all the soil tests for corn except Olsen - and resin-P. 3. Inclusion of $\mathrm{pH}$ with the soil tests improved the prediction of $\mathrm{P}$ uptake for corn from $\mathrm{Bray}-, \mathrm{NH}_{4} \mathrm{OAc}-$, Olsen-, and Al-P as well as Al-P + Fe-P, but had no significant effect on prediction of $\mathrm{P}$ uptake by pine except for $\mathrm{NH}_{4} \mathrm{OAc}-\mathrm{P}$. 4. Inclusion of silt + clay with the soil test values improved predictions of $\mathrm{P}$ uptake by corn from all the soil tests but had no significant effect on prediction for pine.

Organic P significantly correlated with $\mathrm{P}$ uptake in corn (Table 2). As shown above, inclusion of organic $P$ with all the soil tests improved the prediction of $\mathrm{P}$ uptake by pine from only Truog $\mathrm{P}$ and from more of the soil tests in the case of corn. Results in Table 4 showed that silt + clay provided larger increase in $\mathrm{R}^{2}$ for all soil tests than organic P. Since organic $\mathrm{P}$ and silt + clay were significantly correlated it could be that the improvement from including organic $P$ was a reflection of the effect of silt + clay on the or ganic $P$.

The effect of $\mathrm{pH}$ on $\mathrm{P}$ uptake could result fiom the dependence on $\mathrm{pH}$ of the distribution of different inorga:iic $\mathrm{P}$ fractions in the soil and their relative solubility in the extra_tants. It is thought that the 
TABLE 5

$\mathrm{R}^{2}$ values for multiple linear correlations of $\mathrm{P}$ uptake $(\mathrm{mg} / \mathrm{pot})$ by pine on each of the soil tests and other soi properties

\begin{tabular}{|c|c|c|c|c|c|c|c|c|}
\hline \multirow{2}{*}{$\begin{array}{c}\text { Soil } \\
\text { properties }\end{array}$} & \multicolumn{8}{|c|}{ Soil tests } \\
\hline & Truog $\mathrm{P}$ & Bray $\mathrm{P}$ & $\begin{array}{c}\mathrm{NH}_{4} \mathrm{OAC} \\
\mathrm{P}\end{array}$ & $\begin{array}{c}\text { Olsen } \\
\mathbf{p}\end{array}$ & Resin $\mathrm{P}$ & $\mathrm{H}_{2} \mathrm{OP}$ & Al $-\mathrm{P}$ & $\begin{array}{r}\mathrm{Al}-+ \\
\mathrm{Fe}-\mathrm{I}\end{array}$ \\
\hline $\mathrm{OM}$ & $0.491 * *$ & 0.120 & 0.214 & - & $0.661 * *$ & $0.298^{*}$ & $0.258^{*}$ & 0.290 \\
\hline Org. P & $0.555^{* *}$ & $0.176 *$ & $0 .-$ & 1.201 & $0.658^{* *}$ & $0.354 * *$ & $0.312^{*}$ & 0.319 \\
\hline $\mathrm{pH}$ & $0.486 * *$ & 0.140 & $0.283 * *$ & 0.205 & $0.664 * *$ & $0.304 *$ & $0.262^{*}$ & 0.288 \\
\hline SC & $0.501 * *$ & 0.097 & 0.219 & 0.122 & $0.661 * *$ & $0.300^{*}$ & $0.246^{*}$ & $0.283 i$ \\
\hline $\mathrm{OM}+\mathrm{pH}$ & $0.499 * *$ & - & 0.283 & 0.224 & $0.664 * *$ & 0.306 & 0.267 & 0.291 \\
\hline $\mathrm{OM}+\mathrm{pH}+\mathrm{SC}$ & $0.531 * *$ & - & 0.301 & 0.237 & $0.669 * *$ & 0.210 & 0.269 & 0.291 \\
\hline Org. $\mathrm{P}+\mathrm{pH}$ & $0.560^{* *}$ & - & 0.368 & 0.261 & $0.664 * *$ & 0.354 & $0.317^{*}$ & 0.320 \\
\hline Org. $\mathbf{P}+\mathrm{pH}+\mathrm{SC}$ & $0.566 * *$ & -+ & 0.371 & 0.312 & $0.670 * *$ & 0.380 & 0.320 & 0.328 \\
\hline
\end{tabular}

lack of any measurable effect of $\mathrm{pH}$ on pine $\mathrm{P}$ uptake arose solely because of the narrow $\mathrm{pH}$ range (5.0-5.5) of the pine soils.

Linear correlation analyses showed that silt + clay content did not correlate positively and significantly with $\mathrm{P}$ uptake in pine presumably because of little textural variability in the pine soils. Inclusion of silt + clay values with each of the soil tests improved prediction of $\mathrm{P}$ uptake by corn (Table 4). However, it should be recognised that the effect of silt + clay may well be an omnibus of several factors, of which available soil water, mechanism of nutrient supply, textural effects on extractants and nature of the test plants are undoubtedly important. For example, as noted elsewhere in this study, pine seedlings were very vulnerable to root rot on heavy-textured soils and this had caused some seedling deaths.

A factor that can become limiting in the supply of $P$ to plants is the rate of diffusion of $\mathrm{P}$ from the solid phase to the root surface. Among other factors, the rate of $\mathrm{P}$ diffusion will depend on water content of the soil. Fine-textured soils would permit faster diffusion of $\mathrm{P}$ than coarse-textured soils at equivalent soil water potential. Hence, the positive effect of silt + clay on $\mathrm{P}$ uptake in this study could be attributed partly to its effect on the mechanism of $P$ supply. The work of Mahtab et al. ${ }^{15}$ provides further evidence. They found that $\mathrm{P}$ uptake in grain sorghum as well as $\mathrm{P}$ diffusion coefficients 
increased with clay content of four Texas soils. Wilde et al. ${ }^{31}$ found that both texture and soil $\mathrm{P}$ were significant factors in predicting site index of red pine in Wisconsin.

On the basis of $\mathrm{R}^{2}$ values (Tables 4 and 5 ) not all the variability in $P$ uptake of the test plants were explained by the soil variables tested. Other factors not evaluated in this study may be undoubtedly important. It is known, for example, that $\mathrm{Al}$ and $\mathrm{Ca}$ interaction can be involved in $\mathrm{P}$ uptake of eucalyptus seedlings ${ }^{16} ; \mathrm{Al}$ affected $\mathrm{P}$ uptake by $P$. radiata ${ }^{12}$ and $\mathrm{Ca}$ apparently reduced $\mathrm{P}$ uptake in pitch pine 29.

Further analysis of the pine data showed that $0.002 \mathrm{~N} \mathrm{H}_{2} \mathrm{SO}_{4}, 1 \mathrm{~N}$ $\mathrm{NH}_{4} \mathrm{OAc}(\mathrm{pH} 4.8)$, and resin extractable $\mathrm{P}$ were significantly correlated with per cent $\mathrm{P}$ in pine seedling tops; the correlation coefficients, $r$, were $0.414,0.507$ and 0.517 respectively. This is consistent with an earlier work in Wisconsin in which Wilde et al. ${ }^{31}$ found that $0.002 \mathrm{~N} \mathrm{H}_{2} \mathrm{SO}_{4}$ extractable $\mathrm{P}$ was significantly related to site index of red pine.

However, the results of this study showed good agreement with similar work done on forest soils in parts of the U.S. where most conifers either because of site requirements or limitation in available land are usually confined to marginal acid sandy soils. It it becoming increasingly clear that extractants, such as $0.002 \mathrm{~N} \mathrm{H}_{2} \mathrm{SO}_{4}, 1 \mathrm{~N} \mathrm{NH}_{4^{-}}$ $\mathrm{OAc}$ or resin, which remove small amounts of $\mathrm{P}$ are more relevant for predicting fertilizer response of forest species ${ }^{14} 112329$.

\section{CONCLUSIONS}

High dependence of $\mathrm{P}$ extracted by the soil tests on Al-P and Fe-P as established by linear correlations suggest the likelihood of Al-P and Fe-P as the dominant forms of inorganic $\mathrm{P}$ in the soils studied, particularly the acid sandy soils. The correlations of these fractions with $P$ uptake by pine seedlings relate to their importance as sources of available $P$ to the test plants.

Resin extractable $\mathrm{P}$ was superior to any other soil test method for predicting $\mathrm{P}$ uptake by the test plants. $0.002 \mathrm{~N} \mathrm{H}_{2} \mathrm{SO}_{4}$ extractable $\mathrm{P}$ was second in rank. Inclusion of silt + clay values with $0.002 \mathrm{~N}$ $\mathrm{H}_{2} \mathrm{SO}_{4}$ extractable $\mathrm{P}$ and with other soil tests in a multiple regres- 
sion analysis improved prediction of uptake, especially when soils of different textures are involved.

The results support the general observation that extractants which remove small amounts of $P$ are more useful in evaluating short-term $P$ availability in forest soils.

Received 15 February 1977

\section{REFERENCES}

1 Alban, D. H., The relationship of red pine site index to soil phosphorus extracted by several methods. Soil Sci. Soc. Proc. 36, 664-666 (1972).

2 Amer, F., Boulding, D. R., Black, C. A, and Duke, F. R., Characterisation of soil phosphorus by anion exchange resin adsorption and $\mathrm{P}-32$ equilibration. Plant and Soil 6, 391-408 (1955).

3 Bache, B. W. and Rogers, N. E., Soil phosphate values in relation to phosphate supply to plants from some Nigerian soils. J. Agric. Sci. Camb. 74, 383-390 (1970).

4 Baker, James B. and Brendemuchl, R. H., Soil phosphorus level adequate for growth of Ocala sand pine seedlings: A greenhouse eveluation. Soil Sci. Soc. Am. Proc. 36, 666-667 (1972).

5 Bray, R. H. and Kurtz, L. H., Determination of total, organic and available forms of phosphorus in soils. Soil Sci. 59, 39-45 (1945).

6 Chang, S. C, and Jackson, M. L., Fractionation of soil phosphorus, Soil Sci. 84, $133-144(1957)$.

7 Chang, S. C. and Juo, S. R., Available phosphorus in relation to forms of phosphates in soils. Soil Sci. 95, $91-96$ (1962).

8 DeMent, J. A. and Stone, E. L., Influence of soil and site on red pine plantations in New York. II. Soil type and physical properties. Cornell Agric. Exp. Stn. Bull. 1020 (1968).

9 Gunary, D. and Sutton, C. D., Soil factors affecting plant uptake of phosphate. J. Soil Sci. 18, 163-173 (1967).

10 Hesse, P. R., Textbook of Soil Chemical Analysis. John Murray Ltd, London (1971).

11 Humphreys, F. R. and Pritchett, W. L., A soil-testing procedure for predicting phosphorus status of Pinus elliottii plantations. Plant and Soil 37, 479-488 (1972).

12 Humphreys, F. R. and Truman, R., Aluminum and the phosphate requirements of Pinus radiata. Plant and Soil 20, 131-134 (1964).

13 Jackson, M. L., Soil Chemical Analysis. Pretice-Hall, Inc. Englewood Cliffs, N.J. (1958).

$14 \mathrm{John}, \mathrm{M}$. K., Colorimetric determination of phosphorus in soil and plant materials with ascorbic acid. Soil Sci. 109, 214-220 (1970).

15 Mahtab, S. K., Swoboda, A. R., Godfery, C. L. and Thomas, G. W., Phosphorus diffusion in soils. II. The effect of phosphorus uptake by plants. Soil Sci. Soc. Am. Proc. 36, 55-57 (1972).

16 McColl, J. G., Soil-plant relationships in eucalyptus forest on the south coast of New Wales. Ecology 50, 354-362 (1967).

17 Murphy, J. and Riley, J. P., A modified single solution method for the determination of phosphate in natural waters. Anal. Chim. Acta 27, 31-36 (1962).

18 Olsen, S. R., Cole, C. V., Wanatabe, 1. S. and Dean, A. L., Estimation of available phosphorus in soils by extraction with sodium bicarbonate. U.S. Dept. Agric. Circ. 939, 19 pp (1954). 
19 Paauw, F, van der., Calibration of soil test methods for the determination of phosphate and potash status. Plants and Soil 8, 105-125 (1956).

$20 \mathrm{Pack}, \mathrm{M}$. R. and Gomez, S. R., Correlation between plant analyses and soil tests in New Mexico. Soil Sci. Am. Proc. 20, 529-53i (1956).

21 Petersen, G. W. and Corey, R. B., A modified Chang and Jackson procedure for routine fractionation of soil phosphates. Soil Sci. Soc. Am. Proc. 30, 563-565 (1966).

22 Pratt, P. F. and Garber, M. J., Correlation of phosphate availability by chemical, tests with inorganic phosphorus fractions. Soil Sci. Soc. Am. Proc. 28, 23-26 (1964).

23 Pritchett, W. L. and Llewellyn, W. R., Response of slash pine (Pinus elliottii Engelm. var. elliottii) to phosphorus in sandy soils. Soil Sci. Soc. Am. Proc. 30, 509512 (1966).

24 Ralston, C. W., Evaluation of forest site productivity. Int. Rev. For. Res. 1, 171201 (1964).

25 Saunders, W. H. M. and Williams, E. G., Observations on the determination of total organic phosphorus in soils. J. Soil Sci. 6, 254-267 (1955).

26 Sherrell, C. G., Comparison of chemical extraction methods for the determination of available phosphate in soils. N.Z. J. Agric. Res. 13. 481-493 (1970).

27 Susuki, A., Law ton, K. and Doll, E. C., Phosphorus uptake and soil tests as related to forms of phosphorus in some Michigan soils. Soil Sci. Soc. Am. Proc. 27, $401-$ 403 (1963).

28 Truog, E., The determination of readily available phosphorus in soils. J. Am. Soc. Agron. 22, 874-882 (1930).

29 Voigt, G. K., Phosphorus uptake in young pitch pines. Soil Sci. Soc. Am. Proc. 30, 403-406 (1966).

30 Walker, T. W. and Adams, A. F. R., Studies on soil organic matter. I. Influence of phosphorus content of parent materials on accumulation of carbon, nitrogen, sulphur and organic phosphorus in grassland soils. Soil Sci. 85, 307-318 (1958).

31 Wilde, S. A., Iyer, J. G., Tanzer, C., Trautmann, W. L. and Watterston, G. K., Growth of Wisconsin coniferous plantations in relation to soils. Univ. Wis. Agric. Exp. Stn. Res. Bull. 262 (1965). 